\title{
Natural Antioxidants Improve Red Blood Cell "Survival" in Non-Leukoreduced Blood Samples
}

\author{
Yuliya V. Kucherenko ${ }^{a}$ Ingolf Bernhardt \\ aInstitute for Problems of Cryobiology and Cryomedicine of the Ukrainian National Academy of \\ Sciences, Kharkov, Ukraine; bLaboratory of Biophysics, Faculty of Natural and Technical Sciences III, \\ Saarland University, Saarbruecken, Germany
}

\section{Key Words}

Red blood cells - Alsever's solution - Carnosine - Spermine - Phloretin - Phosphatidylserine exposure $\cdot$ Calcium

\begin{abstract}
Background: Blood collected in an anticoagulant can be kept refrigerated in an unmodified state within 5 - 6 weeks. Oxidative damage is considered to be a one of the major factors contributing to the development of storage lesions. Lipid and membrane proteins oxidation results in changes in cation gradients that affect the cell survival. Aim: In the present study we used the natural antioxidants and ion channels blockers (L-carnosine, spermine, phloretin and their mixtures) to prolong "survival" of red blood cells (RBCs), measured as the lack of PS exposure and cell hemolysis, in the Alsever's preservative solution upon hypothermic storage. Results: We show that the mixture of carnosine $(20 \mathrm{mM})$, spermine $(20 \mu \mathrm{M})$ and phloretin $(100 \mu \mathrm{M})$ effectively blunted phosphatidylserine (PS) exposure, $\mathrm{Ca}^{2+}$ accumulation and RBCs hemolysis in non-leukoreduced low ( 2\%) hematocrit samples after 36 days of storage as well as after 1 day of post-storage incubation of the stored cells in physiological saline solution. In addition, a slight but significant decrease in PS exposure was observed in non-leukoreduced high ( 20\%) hematocrit samples after 36 days of storage with the mixture of substances. Conclusion: We conclude that the use of the mixture of natural antioxidants (carnosine, spermine, and phloretin) as an additive to blood preservative solution provides better RBCs storage and "survival".
\end{abstract}

Copyright (C) 2015 S. Karger AG, Basel

\section{Introduction}

Effective preservation and long-term storage of human red blood cells (RBCs) followed by transfusion of the cells to recipient is one of the most important problems in medicine.

Yuliya V. Kucherenko, Ph. D.

KARGER 125
Institute for Problems of Cryobiology and Cryomedicine of the Ukrainian National Academy of Sciences, 23 Pereyaslavskaya Str., 61015 Kharkov (Ukraine)

Tel. +380 57373 4143, Fax +380 57373 3084, E-Mail yulia_kucherenko@yahoo.com 
According to the World Health Organization (WHO) about 107 million blood donations were collected worldwide in 2013. Beside the problems connected with sterility of the blood samples (the absence of pathogenic infection and viruses) there is a general problem of cell survival during the storage and after the transfusion. Cryopreservation of RBCs in highly concentrated glycerol media results in about $80 \%$ survival of de-frozen cells $[1,2]$. However, the method complexities (expensive materials used and post-storage cryoprotectant removal problems) limit the use of cryopreserved blood. Hypothermic storage becomes more popular since no cryoprotectants are used, the cells could be kept in standard refrigerators at $+4{ }^{\circ} \mathrm{C}$ up to 7-10 weeks and could be transfused immediately upon demand. The composition of the media for hypothermic storage involves $\mathrm{Ca}^{2+}$-binding compounds (EDTA/EGTA, citrate), reducing sugars (glucose, mannitol, and sorbitol) and inorganic phosphates to maintain the level of ATP and 2, 3-DPG in the cells.

However, the use of hypothermia for cell storage is limited due to biological and biochemical alterations, known as storage lesions, that include changes in metabolism and cation gradients, oxidation, vesiculation, loss and cross-linking of band 3 , carbonyl modification of band $4.1[3,4]$, elevated PS exposure, reduced deformability and irreversible echinocytosis, hemolysis [5-7]. According to the current theory of storage lesion, the fall in ATP level weakens the cell antioxidant defence resulting in a decline in glutathione peroxidase activity $[3,8]$ and cell damage by reactive oxygen species (ROS). The levels malondialdehyde (MDA), ascorbate (ASC), dehydroascorbic acid (DHA), interleukin-6 (IL-6) were shown to increase significantly during the storage period $[9,10]$ suggesting a progressive oxidative stress in preserved cells. It causes disruption of the cytoskeleton, aggregation of band 3 and release of vesicles $[5-7,11,12]$. At the same time, lipid peroxidation facilitates formation of advanced glycation end products (AGEs). The levels of $\mathrm{HbA}_{1 c^{\prime}}$ a marker of RBC ageing [13] as well as AGE-modified cell surface membrane proteins were reported to increase over storage progression [14-16]. Storage of RBCs in anaerobic conditions was shown to reduce significantly oxidative damage, the rate of hemolysis and PS exposure and, thus, prolonged the cells viability [7].

It is known that about $25 \%$ of long-stored (more than 5 weeks) RBCs are immediately removed from the circulation during the post-transfusion [17]. The recent data showed that overnight incubation at $+37^{\circ} \mathrm{C}$ of 35 days stored RBCs increased cation leakage, hemolysis, PS exposure and vesiculation [18]. Increased cation leakage in stored RBCs could be due to enhanced cation permeability of peroxidised lipid bilayer as well as to activation of the non-selective $\mathrm{Ca}^{2+}$ - permeable cation channels. According to patch-clamp data, that give the evidence of functioning ion channels, there are two types of non-selective $\mathrm{Ca}^{2+}$ - permeable cation channels in erythrocytes: (i) voltage-gated channel, coupled to an acetylcholine receptor [19-21], and (ii) partially related to TRPC6 channels [22] voltage-independent cation channel [23]. The latter was shown to be stimulated by osmotic shock and oxidative stress, the events which accompany cell ageing [24-26]. Recent data demonstrated also the existence of NMDA receptors in rat and human [27-29] and AMPA receptors in human [30] erythrocytes. In addition, the presence of subtypes of voltage-dependent $\mathrm{Ca}^{2+}$ channels was demonstrated by Western blot analysis in age-fractionated erythrocytes [31].

The role of $\mathrm{Ca}^{2+}$ - permeable non-selective cation channels in stimulation of suicidal cell death (also known as eryptosis) is well documented. Eryptosis is known to be triggered by an increase of cytosolic $\mathrm{Ca}^{2+}$ concentration that results in enhanced cell membrane scrambling, cell membrane blebbing, and cell shrinkage [32-35]. Transfusion of hypothermically stored cells, kept in low $\mathrm{Ca}^{2+}$-containing preservative media, induces activation of $\mathrm{Ca}^{2+}$ conductance and thus can stimulate suicidal cell death. Eryptotic cells are quickly eliminated from the blood stream by lymphocytes and macrophages increasing the liver and spleen overload.

Our recent data [36-38] revealed new mechanisms for the non-selective $\left(\mathrm{Ca}^{2+}\right.$-permeable) cation channels regulation in RBCs. The natural cell component polyamine spermine at micromolar concentrations blocks channels activated by $\mathrm{Cl}^{-}$removal as well as the basal activity of the channels in physiological $\mathrm{Cl}^{-}$-containing saline [37]. Moreover, spermine was shown to modulate activity of AMPA/kainate and NMDA receptors in neurons and glial cells 


\section{Cellular Physiology Cell Physiol Biochem 2015;35:2055-2068 \begin{tabular}{ll|l} 
and Biochemistry $\begin{array}{l}\text { DOI: 10.1159/000374012 } \\
\text { Published online: March 31, } 2015\end{array}$ & $\begin{array}{l}\text { O 2015 S. Karger AG, Basel } \\
\text { www.karger.com/cpb }\end{array}$ \\
\cline { 2 - 3 }
\end{tabular} Kucherenko/Bernhardt: Red Blood Cell "Survival"}

[39-40]. Taking into account an anti-oxidative effect of micromolar spermine concentrations [37] we assumed that spermine could be an effective component of preservation solution for hypothermic storage of RBCs.

Natural ageing as well as eryptosis result in osmotic cell water loss and cell shrinkage. Recently we showed that aquaporin 9 (AQP9) contributes to cation permeability of erythrocytes either acting as a cation-conducting channel or by regulating the activity of other cation channels [38]. Addition of phloretin, a natural antioxidant [41-42] that blocks the glucose transporter [43] and water channels [44], to RBC preservative solution could prevent the cell shrinkage and, thus, increase the cell survival.

Non-enzymatic glycation is a non-enzymatic irreversible process that is promoted by the prolonged exposure of RBCs to high glucose concentrations, a condition that is known to occur under low temperature blood preservation [15]. Progressive accumulation of glycated end products was observed upon hypothermic storage of RBCs [14]. Our recent data [36] demonstrated that glycated human RBCs showed enhanced activity of the non-selective $\left(\mathrm{Ca}^{2+}-\right.$ permeable) cation channels that results in $\left[\mathrm{Ca}^{2+}\right]_{\mathrm{i}}$ increase, cell shrinkage and PS exposure. We supposed that L-carnosine, ROS scavenger [45] and inhibitor of non-enzymatic glycation [46], when used as a component of blood preservative solution, could prevent formation of glycated end products and improve stored cell survival.

Thus, in the present study we used the known antioxidants (L-carnosine, spermine and phloretin) to prolong RBCs "survival", measured as the lack of PS exposure and cell hemolysis (if detected), in Alsever's protective solution upon 36 days of hypothermic storage.

\section{Materials and Methods}

Blood

Experiments with human RBCs were authorized by the ethics committee of the medical association of the Saarland under registration number 132/08. Blood donors provided their written informed consent to participate in this study. For the experiments, we used RBCs from healthy adult donors. Blood was vein drawn into heparinized syringes.

Sample preparation

The blood samples for long-term storage at $+4{ }^{\circ} \mathrm{C}$ were made under sterile conditions. Sterile Alsever's preservative solution (Sigma, Germany) was used.

Low hematocrit (approximately 2\%) and high hematocrit (approximately 20\%) samples were made by mixing whole blood with Alsever's solution in the presence of 10 and $20 \mathrm{mM}$ carnosine; 20 and $200 \mu \mathrm{M}$ spermine; $100 \mu \mathrm{M}$ phloretin; and the mixures of $20 \mathrm{mM}$ carnosine and $20 \mu \mathrm{M}$ spermine; $20 \mathrm{mM}$ carnosine $20 \mu \mathrm{M}$ spermine and $100 \mu \mathrm{M}$ phloretin. The blood samples preserved in Alsever's solution without additives were used as controls. Alsever's solution contained (g/L): $4.2 \mathrm{NaCl}, 8 \mathrm{Na}$-citrate $* 2 \mathrm{H}_{2} \mathrm{O}, 0.55$ citric acid and 20.5 D-glucose.

The samples stored at $+4{ }^{\circ} \mathrm{C}$ were checked for cytosolic free $\mathrm{Ca}^{2+}$ concentration (Fluo4 fluorescence) and PS exposure (Annexin V binding) at 1, 3, 8, 22 and 36 days of storage.

After 36 days of hypothermic storage the preservative media were removed (short spin, $15 \mathrm{~s}, 16,000$ $\mathrm{g}$ ), the cells were re-suspended in physiological saline solution ( $\mathrm{pH} 7.4$ ) and incubated for $24 \mathrm{~h}$ at $+37^{\circ} \mathrm{C}$. Physiological saline solution consisted of (in mM): $145 \mathrm{NaCl}, 7.5 \mathrm{KCl}, 2 \mathrm{CaCl}_{2}, 10$ glucose and $10 \mathrm{HEPES}$ (pH 7.4 with $\mathrm{NaOH}$ ). Then the cells were again checked for PS exposure (Annexin $\mathrm{V}$ binding).

Hemolysis in the supernatants was measured after the hypothermic storage (36 days) and after 1 day incubation in physiological saline solution.

Intracellular free $\mathrm{Ca}^{2+}$ measurements

Intracellular free $\mathrm{Ca}^{2+}$ was analyzed by flow cytometry using the $\mathrm{Ca}^{2+}$-sensitive probe Fluo4. RBCs $\left(0.1 \%\right.$ hematocrit) were loaded with Fluo4 $(1 \mu \mathrm{M})$ and incubated for $30 \mathrm{~min}$ at $+37{ }^{\circ} \mathrm{C}$. Then extracellular Fluo4 was removed (10 s, 16,000 g, Eppendorf, 5415 D centrifuge) by aspiration and the cell pellet was resuspended in physiological saline solution. The cells $(30,000)$ were than analyzed using a flow cytometer (FACS-Calibur, Becton Dickinson Biosciences, USA) in FL-1 channel with $488 \mathrm{~nm}$ excitation and $530 \mathrm{~nm}$ 


\section{Cellular Physiology Cell Physiol Biochem 2015;35:2055-2068 \begin{tabular}{l|l} 
and Biochemistry Published online: March 31, 2015 & $\begin{array}{l}\text { C) 2015 S. Karger AG, Basel } \\
\text { www.karger.com/cpb }\end{array}$ \\
\hline
\end{tabular} \\ Kucherenko/Bernhardt: Red Blood Cell "Survival"}

emission wavelengths. The data were processed using BD Cell Quest Pro Software (Becton Dickinson Biosciences, USA).

Phosphatidylserine exposure measurements

The cells (0.1\% hematocrit) were stained with Annexin V-FITC (Invitrogen, Molecular Probes, Germany) at a 1:125 dilution in $2 \mathrm{mM} \mathrm{Ca}^{2+}$-containing physiological saline solution. After 20 min of incubation samples were measured by flow cytometric analysis (FACS-Calibur from Becton Dickinson; USA). Annexin V-FITC fluorescence intensity was measured in fluorescence channel FL-2 with an excitation wavelength of $488 \mathrm{~nm}$ and an emission wavelength of $530 \mathrm{~nm}$.

\section{Hemolysis measurements}

RBC hemolysis was estimated as oxyhemoglobin $(\mathrm{Oxy}-\mathrm{Hb})$ release. Oxy-Hb was measured in supernatants with UV-VIS spectrophotometer (UVmini-1240, Shimadzu, Japan) at $577 \mathrm{~nm}$ wavelength. Concentration of $\mathrm{Oxy}-\mathrm{Hb}$ was calculated from the adsorption data using the molar extinction coefficient of $14.6 \mathrm{mM}^{-1} \times \mathrm{cm}^{-1}$ per heme.

Chemicals and solutions

All the chemicals used were of the highest grade. Alsever's solution, carnosine and phloretin were from Sigma (Germany), spermine from Roth (Germany).

Statistics

The experiments were done in triplicate using blood of different blood donors. Data are presented as arithmetic means \pm SEM. Unpaired two-tailed t-test was employed as appropriate, $p<0.05$ and $p<0.01$ were considered statistically significant.

\section{Results}

Alsever's solution, an isotonic, anticoagulant blood preservative, had proved satisfactory with the usual criteria for studying RBC preservation; that is, rate of spontaneous hemolysis, fragility tests, hemoglobin levels, and incidence of reactions. However, ageing of RBCs preserved in Alsever's solution was not tested. In the present study we explored the changes in the cells "survival", measured as the lack of PS exposure and (in some cases) hemolysis, during 36 days storage of blood in Alsever's solution.

In the first series of experiments we used high ( 20\%) hematocrit blood samples prepared according to the standard procedure by mixing one part of Alsever's solution with one part of whole blood.

Fig. 1A shows changes in Annexin $\mathrm{V}$ binding of the RBCs upon storage in Alsever's solution. No significant changes in Annexin $V$ binding were observed in the cells during the first 2 weeks of storage. Percentage of PS-exposing cells significantly increased after 3 weeks of storage and reached the value of $6.93 \pm 0.36$ after 5 weeks of hypothermic storage.

The use of carnosine (10 and $20 \mathrm{mM}$, Fig. 1B and C) and spermine (20 $\mu \mathrm{M}$ and 200 $\mu \mathrm{M}$, Fig. 1D and E) as additives to Alsever's solution did not significantly improve the cell "survival". In opposite, $100 \mu \mathrm{M}$ phloretin alone (Fig. 1F) and in combination with carnosine and spermine (Fig. 1G and H) blunted PS exposure after 6 weeks of cell storage. PS exposure in the cells suspended in Alsever's solution containing carnosine, spermine and phloretin was significantly lower than in control cells ( $4.41 \pm 0.03$ versus $6.93 \pm 0.36$ for control cells) after 36 days of storage (Fig. 2A, B and E).

Since PS exposure could be due to an increase in cytosolic free $\mathrm{Ca}^{2+}$ concentration $\left(\left[\mathrm{Ca}^{2+}\right]_{\mathrm{i}}\right)$, with stimulation of $\mathrm{Ca}^{2+}$-dependent scramblase activity, we measured the changes in $\left[\mathrm{Ca}^{2+}\right]_{\mathrm{i}}$ during cell storage. As it is shown in Fig. $1 \mathrm{~A}$, a cell population with elevated Fluo4 intensity (highly Fluo4 fluorescent cells) tended to increase upon cell storage, indicating a total $\left[\mathrm{Ca}^{2+}\right]_{\mathrm{i}}$ increase. However, no linear correlation between $\left[\mathrm{Ca}^{2+}\right]_{i}$ and PS exposure in the cells preserved in Alsever's solution either in the absence or presence of the additives was 


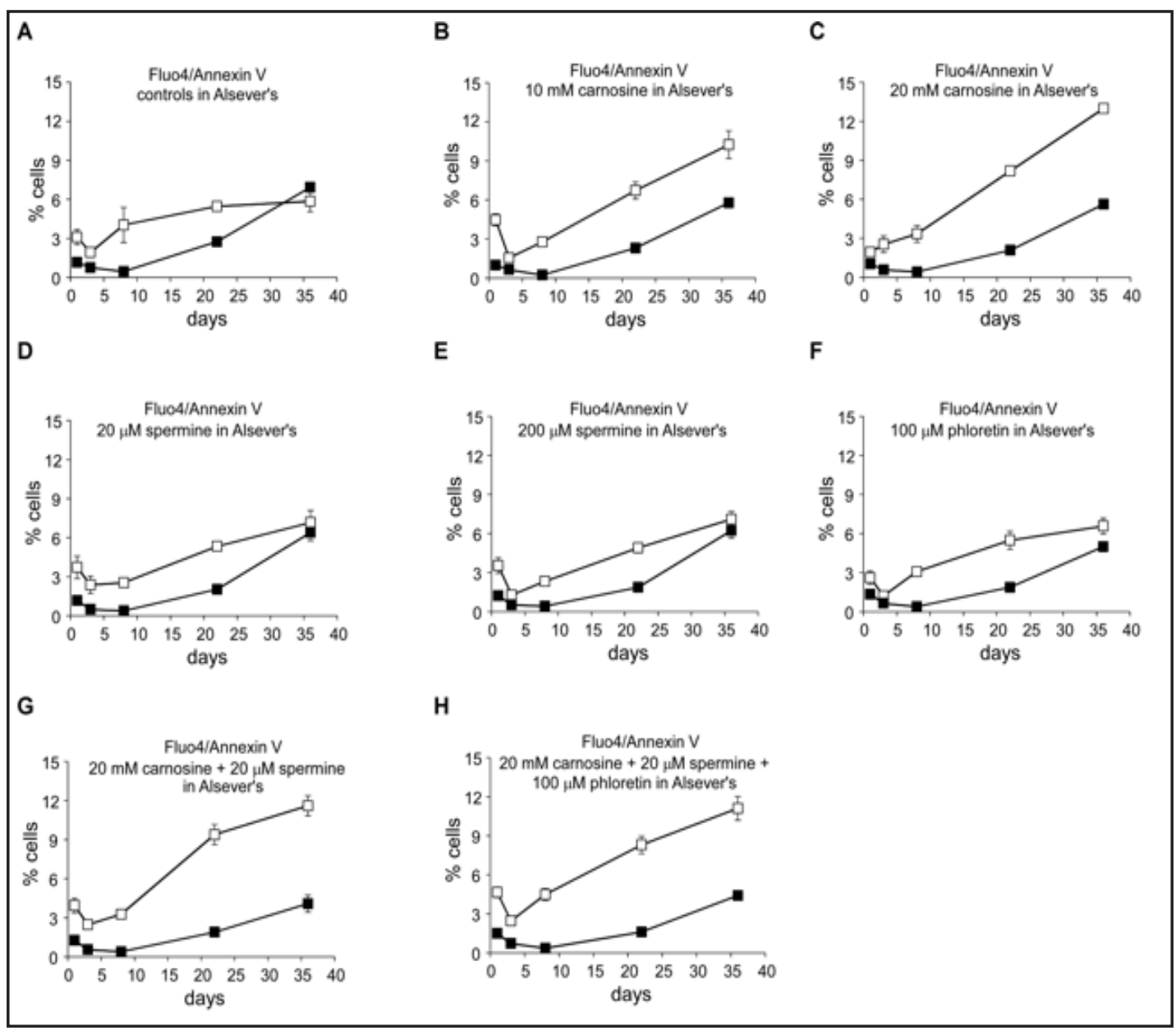

Fig. 1. Time-dependent changes in Annexin V binding and Fluo4 fluorescence in high ( 20\%) hematocrit blood samples preserved with Alserver's solution. A. Annexin V binding (closed squares, $\mathrm{n}=3$ ) and highly Fluo4 fluorescent (open squares, $n=3$ ) RBCs ( $\%$ of cells), stored $\left(+4{ }^{\circ} \mathrm{C}\right.$ ) for $1,3,8,22$ and 36 days in Alserver's preservative solution. B. as in A. in the presence of $10 \mathrm{mM}$ carnosine. C. as in A. in the presence of $20 \mathrm{mM}$ carnosine. D. as in A. in the presence of $20 \mu \mathrm{M}$ spermine. E. as in A. in the presence of $200 \mu \mathrm{M}$ spermine.F. as in A. in the presence of $100 \mu \mathrm{M}$ phloretin. G. as in A. in the presence of $20 \mathrm{mM}$ carnosine and $200 \mu \mathrm{M}$ spermine.H. as in A. in the presence of $20 \mathrm{mM}$ carnosine, $200 \mu \mathrm{M}$ spermine and $100 \mu \mathrm{M}$ phloretin.

found. Moreover, we observed a significant increase in $\left[\mathrm{Ca}^{2+}\right]_{\mathrm{i}}$ and a decrease in Annexin $\mathrm{V}$ binding in the cells suspended in the carnosine containing Alsever's solution (Fig. 1 and 2).

At the same time, carnosine blunted PS exposure as well as $\left[\mathrm{Ca}^{2+}\right]_{\mathrm{i}}$ increase in highly diluted ( $\sim 2 \%$ hematocrit) blood samples (Fig. 3 and Fig. 4).

Similarly to what was observed with high hematocrit blood samples, the mixture consisting of carnosine, spermine and phloretin was the most effective in protection of low hematocrit blood samples against increase of PS exposure ( $4.84 \pm 0.86$ for the mixture treated cells in comparison with $15.72 \pm 1.91$ for control cells) after 36 days of storage (Fig. $3 \mathrm{H}$ and Fig. 4). Moreover, the cell samples preserved with the mixture accumulated significantly less $\mathrm{Ca}^{2+}$ than control cells $(7.36 \pm 0.03$ versus $9.4 \pm 0.23$ for control cells).

Noteworthy, spermine alone at high concentration $(200 \mu \mathrm{M})$ demonstrated a strong protection, blocking the time-dependent increase in $\left[\mathrm{Ca}^{2+}\right]_{\mathrm{i}}$ and PS exposure in low hematocrit blood samples (Fig. 3E and Fig. 4). The effect was comparable with the effect of the carnosinespermine- phloretin mixture (Fig. 4). The data on low hematocrit blood samples showed that, in most cases, PS exposure and intracellular free $\mathrm{Ca}^{2+}$ levels were coupled. Thus, enhanced PS exposure in the preserved cells was paralleled by an increase in $\left[\mathrm{Ca}^{2+}\right]_{\mathrm{i}^{*}}$ 


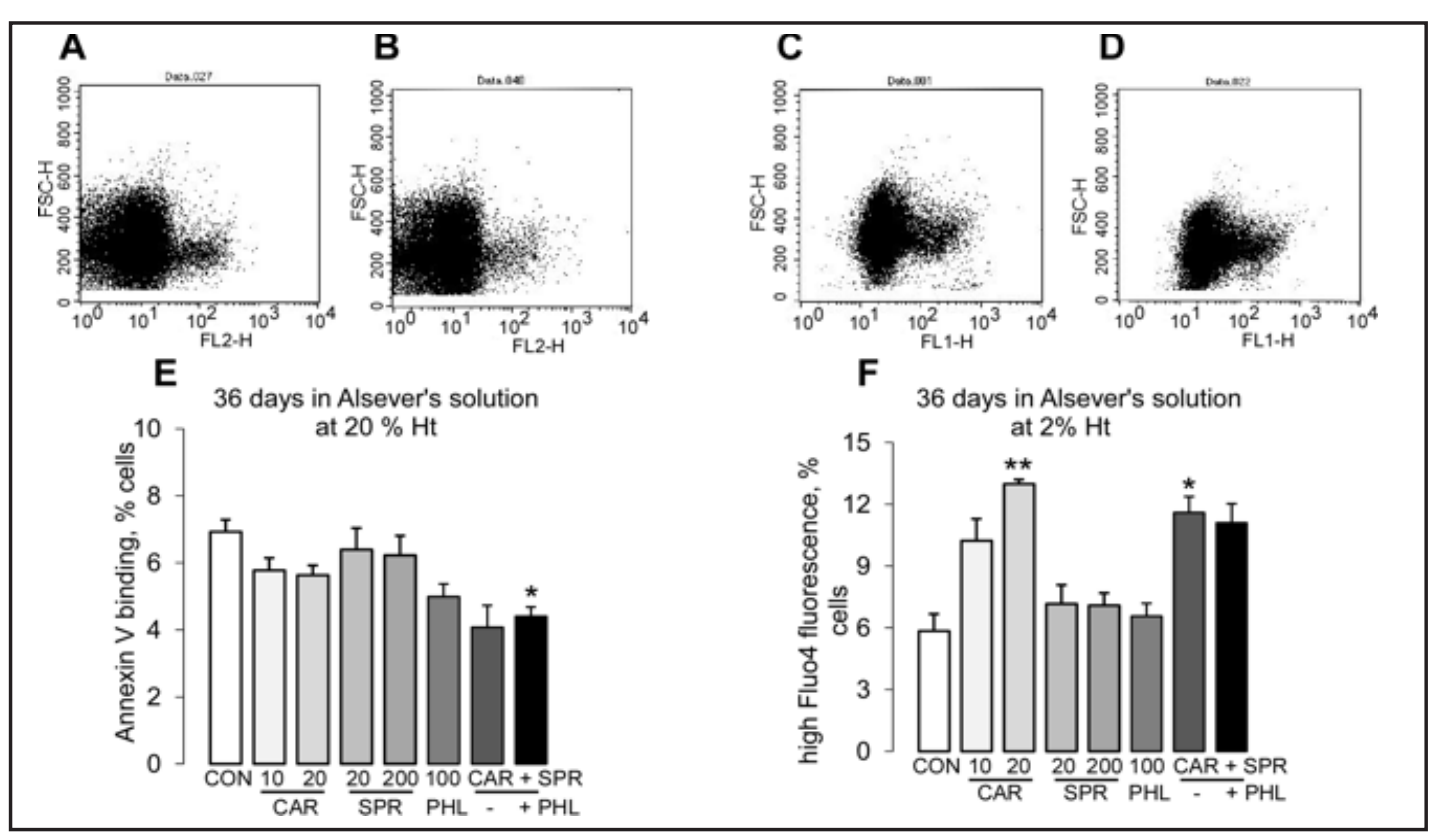

Fig. 2. Annexin $V$ binding and Fluo4 fluorescence in high $(\sim 20 \%)$ hematocrit blood samples stored at $+4{ }^{\circ} \mathrm{C}$ in Alserver's solution for 36 days. A., B. Flow cytometric histograms of Annexin V binding in representative experiments on blood samples stored at $+4{ }^{\circ} \mathrm{C}$ for 36 days in Alsever's solution in the absence (A.) and the presence of the mixture consisting of $20 \mathrm{mM}$ carnosine, $200 \mu \mathrm{M}$ spermine and $100 \mu \mathrm{M}$ phloretin (B). C., D. Flow cytometric histograms of Fluo4 fluorescence in representative experiments on blood samples stored at $+4{ }^{\circ} \mathrm{C}$ for 36 days in Alsever's solution in the absence (C.) and the presence of the mixture consisting of $20 \mathrm{mM}$ carnosine, $200 \mu \mathrm{M}$ spermine and $100 \mu \mathrm{M}$ phloretin (D.). E. Arithmetic means \pm SEM of Annexin V binding (\%) in blood samples stored at $+4{ }^{\circ} \mathrm{C}$ for 36 days in Alsever's solution in the absence of additives (white bar, $\mathrm{n}=3$ ), in the presence of $10 \mathrm{mM}$ and $20 \mathrm{mM}$ carnosine (light grey bars, $\mathrm{n}=3$ ), $20 \mu \mathrm{M}$ and 200 $\mu \mathrm{M}$ spermine (grey bars, $\mathrm{n}=3$ ), $100 \mu \mathrm{M}$ phloretin (dark grey bar, $\mathrm{n}=3$ ), mixture of $20 \mathrm{mM}$ carnosine and $200 \mu \mathrm{M}$ spermine (dark grey bar, $\mathrm{n}=3$ ) and mixture of $20 \mathrm{mM}$ carnosine, $200 \mu \mathrm{M}$ spermine and $100 \mu \mathrm{M}$ phloretin (black bar, $\mathrm{n}=3$ ). * indicates significant difference from control cells $(\mathrm{p}<0.05$; unpaired t-test). F. as in E. for Fluo4 fluorescence. * and ** indicate significant difference from control cells $(\mathrm{p}<0.05$ and $\mathrm{p}<0.01$, respectively; unpaired t-test).

In the next series of experiments we modeled the situation of transfusing the stored cells to a patient to check the cell "survival" in blood stream. For this, we incubated the 36 days stored cells in physiological saline solution for 1 day at $37^{\circ} \mathrm{C}$ and then measured Annexin $\mathrm{V}$ binding to the cells and oxy-Hb release in the cell supernatants as an index of cell lysis.

As it is shown in Fig. 5 (compare with control samples of Fig. 2 and Fig. 4, Annexin $\mathrm{V}$ binding), 1 day treatment in physiological saline solution of control cells preserved in Alsever's solution dramatically stimulated Annexin V binding in high-hematocrit (6.93 \pm 0.36 and $31.09 \pm 2.91$, before and after the incubation, respectively) as well as in low-hematocrit (15.72 \pm 1.91 and $35.66 \pm 1.88$, before and after the incubation, respectively) blood samples.

The high-hematocrit cell samples preserved with the mixture of carnosine, spermine and phloretin did not show a significant difference in Annexing binding levels in comparison with control cells after the incubation in physiological saline solution (Fig. 5A).

In opposite, the incubation $\left(1\right.$ day, $\left.+37^{\circ} \mathrm{C}\right)$ of low-hematocrit blood samples, preserved with the mixture of carnosine, spermine and phloretin, resulted in a significantly lower value of PS exposing cells $(9.32 \pm 1.18$ versus $35.66 \pm 1.89)$ in comparison with control cells preserved in Alsever's solution without additives (Fig. 5B). Interestingly, all additives and mixtures, except $20 \mu \mathrm{M}$ spermine (that was ineffective) and $100 \mu \mathrm{M}$ phloretin (that highly enhanced PS exposure), significantly blunted PS exposure in low hematocrit blood samples upon the post-incubation (Fig. 5B).

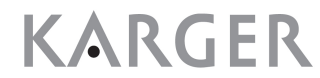




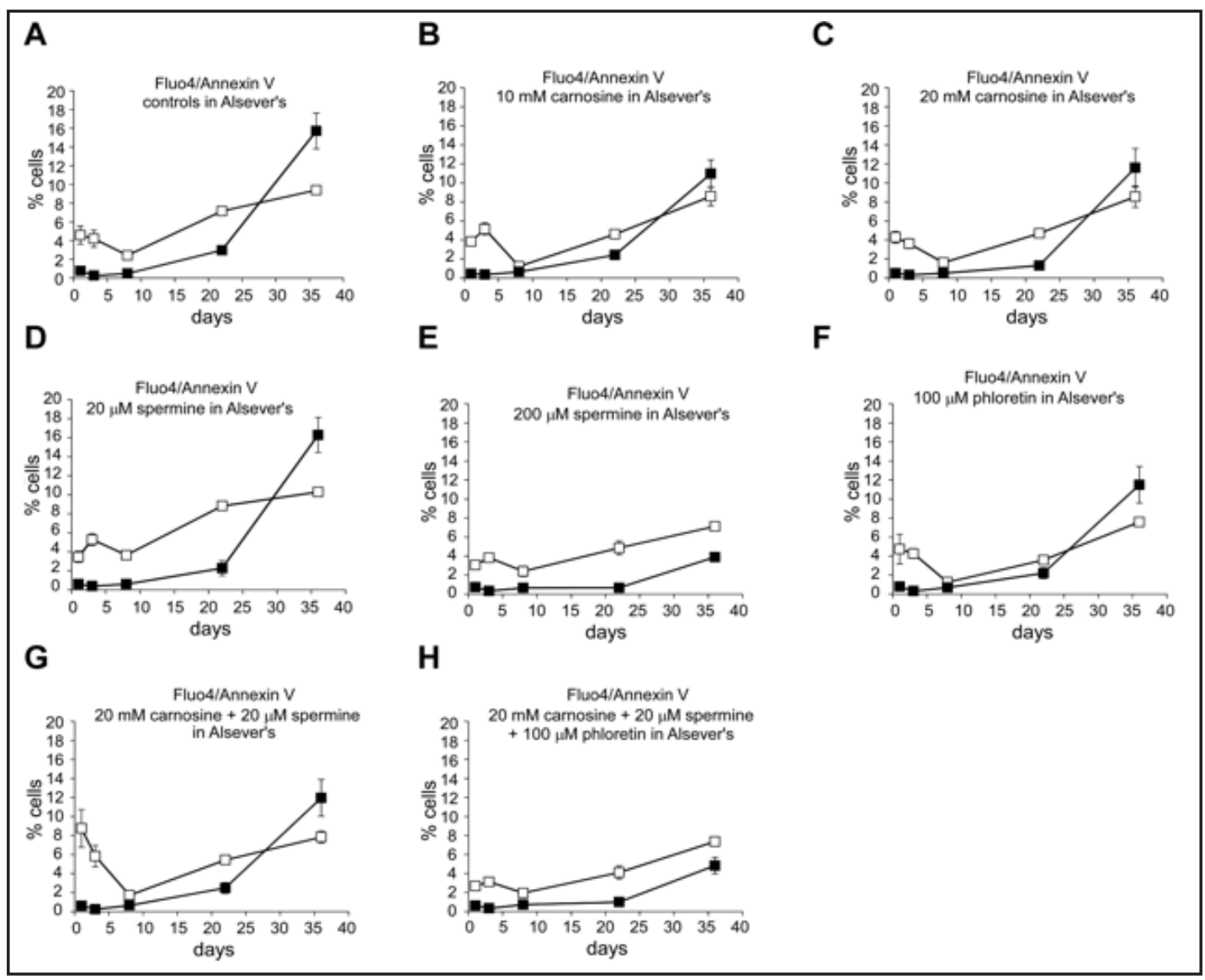

Fig. 3. Time-dependent changes in Annexin $\mathrm{V}$ binding and Fluo4 fluorescence in low ( 2\%) hematocrit blood samples preserved with Alserver's solution. A. Annexin V binding (closed squares, $\mathrm{n}=3$ ) and highly Fluo4 fluorescent (open squares, $n=3$ ) RBCs ( $\%$ of cells), stored $\left(+4{ }^{\circ} \mathrm{C}\right.$ ) for $1,3,8,22$ and 36 days in Alserver's preservative solution. B. as in A. in the presence of $10 \mathrm{mM}$ carnosine. C. as in A. in the presence of $20 \mathrm{mM}$ carnosine. D. as in A. in the presence of $20 \mu \mathrm{M}$ spermine. E. as in A. in the presence of $200 \mu \mathrm{M}$ spermine.F. as in A. in the presence of $100 \mu \mathrm{M}$ phloretin. G. as in A. in the presence of $20 \mathrm{mM}$ carnosine and $200 \mu \mathrm{M}$ spermine. H. as in A. in the presence of $20 \mathrm{mM}$ carnosine, $200 \mu \mathrm{M}$ spermine and $100 \mu \mathrm{M}$ phloretin.

In addition, the post-incubation of high hematocrit cell samples preserved with the mixture of carnosine, spermine and phloretin did not enhance significantly the cell hemolysis (measured as free oxyhemoglobin release in supernatants). However, in low hematocrit cell samples the mixture of carnosine, spermine and phloretin effectively protected the cells against destruction (Fig. 6).

\section{Discussion}

The present study was performed with Alsever's blood preservative solution. The solution was developed in the USA during the World War II and it is still routinely used as whole blood (or packed RBCs) preservative and is the only blood preservative available from Sigma. Maximal storage time for blood preserved with Alsever's solution is announced as 10 weeks. In our study, however, a shorter storage period (36 days) that is typically used in blood preservation practice was applied.

Literature data showed that antioxidants given either to blood donors [47] or to storage solutions $[2,48]$ improve RBCs storage parameters by reducing free radical cell damage. The most promising results could be expected when antioxidants effectively inhibit cation 


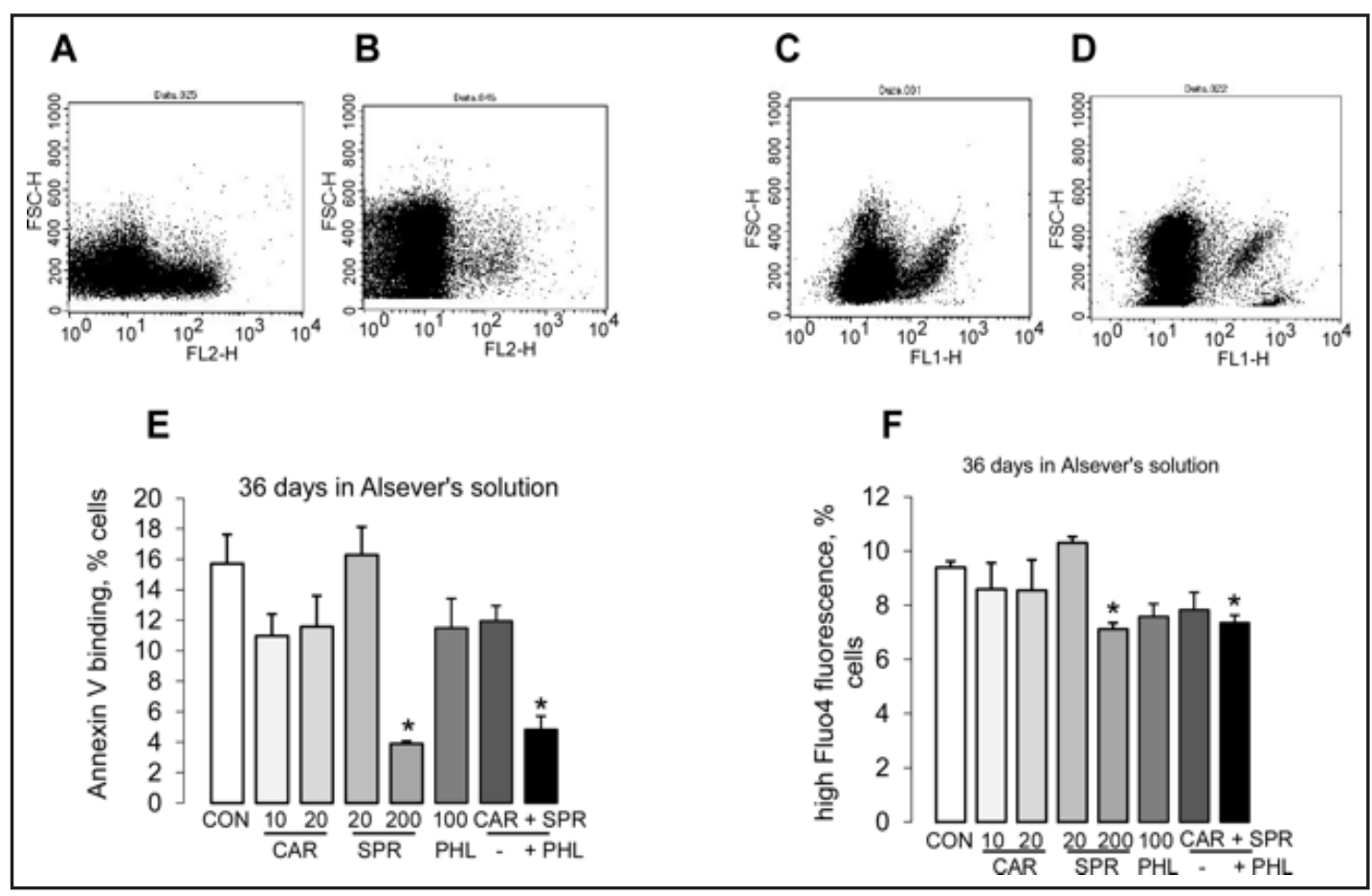

Fig. 4. Annexin $\mathrm{V}$ binding and Fluo4 fluorescence in low ( 2\%) hematocrit blood samples stored at $+4{ }^{\circ} \mathrm{C}$ in Alserver's solution for 36 days. A., B. Flow cytometric histograms of Annexin V binding in representative experiments on blood samples stored at $+4{ }^{\circ} \mathrm{C}$ for 36 days in Alsever's solution in the absence (A.) and the presence of the mixture consisting of $20 \mathrm{mM}$ carnosine, $200 \mu \mathrm{M}$ spermine and $100 \mu \mathrm{M}$ phloretin (B). C., D. Flow cytometric histograms of Fluo4 fluorescence in representative experiments on blood samples stored at $+4{ }^{\circ} \mathrm{C}$ for 36 days in Alsever's solution in the absence (C) and the presence of the mixture consisting of 20 $\mathrm{mM}$ carnosine, $200 \mu \mathrm{M}$ spermine and $100 \mu \mathrm{M}$ phloretin (D). E. Arithmetic means \pm SEM of Annexin $\mathrm{V}$ binding (\%) in blood samples stored at $+4{ }^{\circ} \mathrm{C}$ for 36 days in Alsever's solution in the absence of additives (white bar, $\mathrm{n}=3$ ), in the presence of $10 \mathrm{mM}$ and $20 \mathrm{mM}$ carnosine (light grey bars, $\mathrm{n}=3$ ), $20 \mu \mathrm{M}$ and $200 \mu \mathrm{M}$ spermine (grey bars, $\mathrm{n}=3$ ), $100 \mu \mathrm{M}$ phloretin (dark grey bar, $\mathrm{n}=3$ ), mixture of $20 \mathrm{mM}$ carnosine and $200 \mu \mathrm{M}$ spermine (dark grey bar, $\mathrm{n}=3$ ) and mixture of $20 \mathrm{mM}$ carnosine, $200 \mu \mathrm{M}$ spermine and $100 \mu \mathrm{M}$ phloretin (black bar, $\mathrm{n}=3$ ). * indicates significant difference from control cells ( $\mathrm{p}<0.05$; unpaired t-test). F. as in E. for Fluo4 fluorescence. * and ** indicate significant difference from control cells $(\mathrm{p}<0.05$ and $\mathrm{p}<0.01$, respectively; unpaired t-test).

leakage $[49,50]$. Based on our recent data [36 - 38] we selected three substances (carnosine, spermine and phloretin) that meet the above criteria, i.e. they are antioxidants of natural origin that show blocking effects on cation channels.

We supposed that the use of carnosine, spermine and phloretin as additives to blood preservative solutions could provide better "survival" of RBCs during storage and after the cells transfusion.

The experiments were performed with high and low hematocrit non-leukoreduced blood samples. It allowed us to study the effect of blood components on the stored RBC "survival". Since the life-time of white blood cells and platelets is short in comparison with RBCs, varying from hours to 3-4 days for white cells and 5-9 days for platelets, plasma components and the substances released by dead leukocytes/platelets can affect preserved RBCs survival. Residual white blood cells and platelets were shown [51] to represent a stressful storage factor, countering the structural and functional integrity of stored RBCs. Hemolysis, irreversible echinocytosis, microvesiculation, ROS and $\mathrm{Ca}^{2+}$ accumulation, band 3 related senescence modifications, membrane proteome stress biomarkers were recorded mostly in non-leukoreduced RBCs compared to leukoreduced RBCs. Plasma could have a dual 


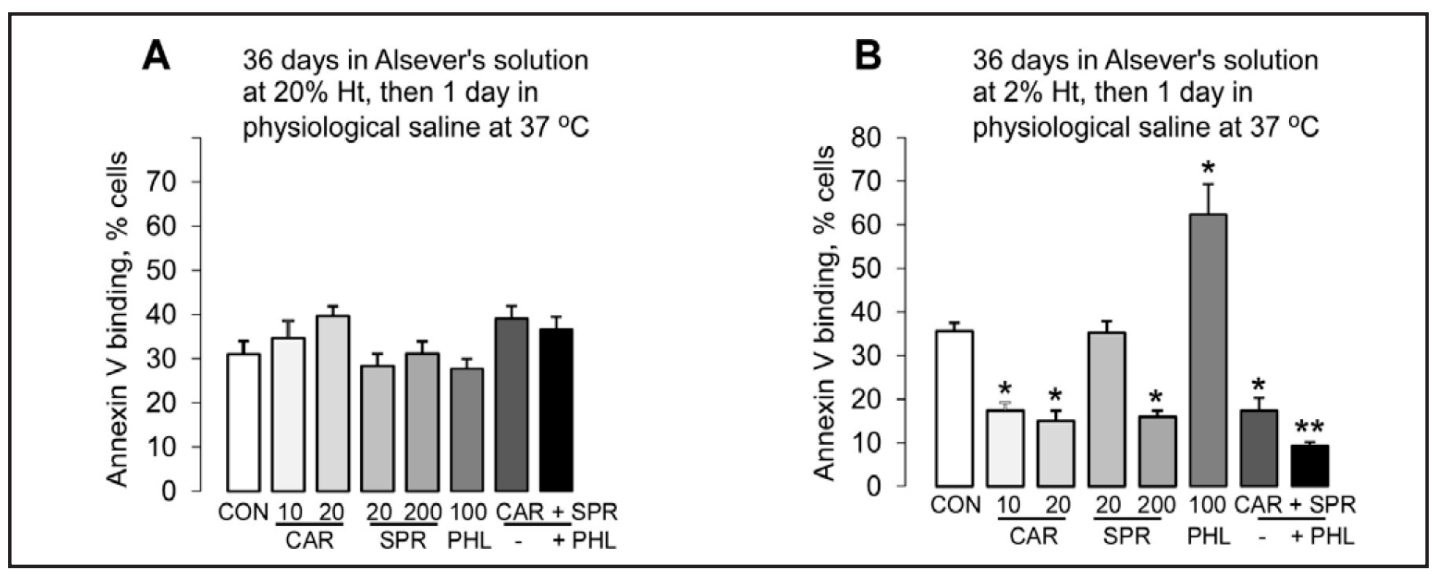

Fig. 5. Annexin $\mathrm{V}$ binding in the hypothermically preserved cells after $24 \mathrm{~h}$ incubation at $+37^{\circ} \mathrm{C}$ in physiological saline solution. A. Annexin V binding in high ( 20\%) hematocrit samples preserved in Alserver's solution $\left(+4{ }^{\circ} \mathrm{C}, 36\right.$ days) solution in the absence of additives (white bar, $\mathrm{n}=3$ ), in the presence of $10 \mathrm{mM}$ and $20 \mathrm{mM}$ carnosine (light grey bars, $\mathrm{n}=3$ ), $20 \mu \mathrm{M}$ and $200 \mu \mathrm{M}$ spermine (grey bars, $\mathrm{n}=3$ ), $100 \mu \mathrm{M}$ phloretin (dark grey bar, $\mathrm{n}=3$ ), mixture of $20 \mathrm{mM}$ carnosine and $200 \mu \mathrm{M}$ spermine (dark grey bar, $\mathrm{n}=3$ ) and mixture of $20 \mathrm{mM}$ carnosine, $200 \mu \mathrm{M}$ spermine and $100 \mu \mathrm{M}$ phloretin (black bar, $\mathrm{n}=3$ ), then incubated for $24 \mathrm{~h}$ at $+37^{\circ} \mathrm{C}$ in physiological saline solution. B. as in A. for low $(\sim 2 \%)$ hematocrit cells.

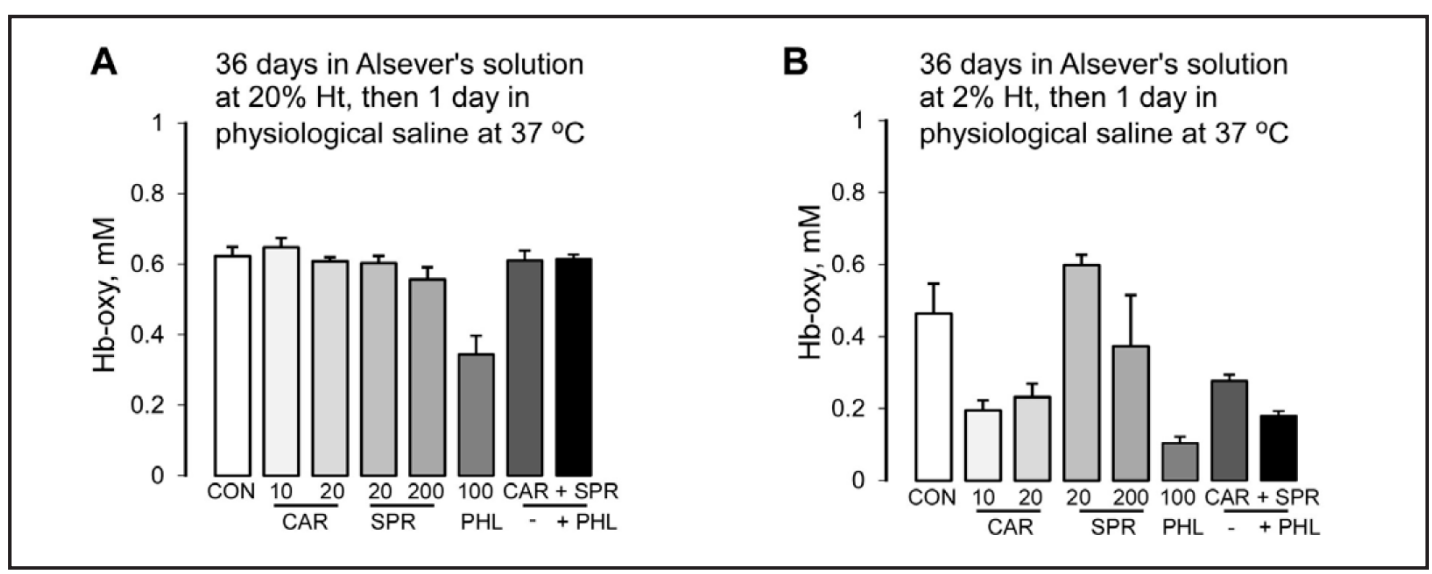

Fig. 6. Free oxy-Hb release in the hypothermically preserved cells after $24 \mathrm{~h}$ incubation at $+37^{\circ} \mathrm{C}$ in physiological saline. A. Hemolysis, measured as free oxy-Hb release in supernatants of high $(\sim 20 \%)$ hematocrit samples preserved in Alserver's solution $\left(+4{ }^{\circ} \mathrm{C}, 36\right.$ days) solution in the absence of additives (white bar, $\mathrm{n}=3$ ), in the presence of $10 \mathrm{mM}$ and $20 \mathrm{mM}$ carnosine (light grey bars, $\mathrm{n}=3$ ), $20 \mu \mathrm{M}$ and $200 \mu \mathrm{M}$ spermine (grey bars, $\mathrm{n}=3$ ), $100 \mu \mathrm{M}$ phloretin (dark grey bar, $\mathrm{n}=3$ ), mixture of $20 \mathrm{mM}$ carnosine and $200 \mu \mathrm{M}$ spermine (dark grey bar, $\mathrm{n}=3$ ) and mixture of $20 \mathrm{mM}$ carnosine, $200 \mu \mathrm{M}$ spermine and $100 \mu \mathrm{M}$ phloretin (black bar, $\mathrm{n}=3$ ), then incubated for $24 \mathrm{~h}$ at $+37^{\circ} \mathrm{C}$ in physiological saline solution. B. as in A. for low ( 2\%) hematocrit cells.

effect on RBCs survival. It is known to possess an antioxidant activity and, thus, to protect the cells against oxidative stress. The major substances contributing to total antioxidant capacity of plasma are free radical scavengers (albumin, urate, ascorbate, bilirubin), metalbinding antioxidants (caeruloplasmin and transferrin) and vitamins (alpha tocopherol, betacarotene, retinol and ascorbic acid, cobalamin) [52, 53]. However, plasma components could also interact with additives present in blood preservative solutions, resulting in the formation of cytotoxic products [54]. Moreover, plasma proteins (serum albumin, apolipoprotein A1, transferrin) undergo oxidation [55] and non-enzymatic glycation [56] upon storage in sugar enriched protective media that result in increased oxidative damage of stored RBCs. 


\section{Cellular Physiology Cell Physiol Biochem 2015;35:2055-2068 \begin{tabular}{l|l|l}
\hline DOI: $10.1159 / 000374012$ & C 2015 S. Karger AG, Basel
\end{tabular}

Table 1. RBCs "survival" (measured as \% of cells exposing no PS) and oxy-Hb release (mM) in the cells suspensions ( $\sim 2$ and $\sim 20 \%$ hematocrit) preserved $\left(+4{ }^{\circ} \mathrm{C}, 36\right.$ days $)$ in Alsever's solution in the absence (control) or presence of the mixture of $20 \mathrm{mM}$ carnosine, $20 \mu \mathrm{M}$ spermine and $100 \mu \mathrm{M}$ phloretin and then incubated $\left(24 \mathrm{~h},+37^{\circ} \mathrm{C}\right)$ in physiological saline solution. * and ${ }^{* *}$ indicate significant difference from control $(\mathrm{p}<0.05$ and $\mathrm{p}<0.01$, respectively; unpaired t-test). \# No oxy-Hb release was detected in the cells samples after 36 days storage at $+4{ }^{\circ} \mathrm{C}$

\begin{tabular}{|c|c|c|c|c|c|}
\hline & \multicolumn{2}{|c|}{ RBCs "survival", \% cells } & \multicolumn{2}{|c|}{ oxy-Hb release, $\mathrm{mM}$} \\
\hline & & storage & incubation & storage\# & incubation \\
\hline \multirow[t]{2}{*}{$\sim 2 \%$ hematocrit } & control & $87.38 \pm 1.41$ & $64.34 \pm 1.89$ & - & $0.46 \pm 0.08$ \\
\hline & mixture & $95.16 \pm 0.86^{*}$ & $90.68 \pm 1.18^{* *}$ & - & $0.18 \pm 0.01$ \\
\hline \multirow[t]{2}{*}{$\sim 20 \%$ hematocrit } & control & $93.07 \pm 0.36$ & $69.48 \pm 1.35$ & - & $0.62 \pm 0.02$ \\
\hline & mixture & $95.59 \pm 0.27^{*}$ & $63.37 \pm 2.84$ & - & $0.61 \pm 0.01$ \\
\hline
\end{tabular}

The effectiveness of the additives to Alserver's protective solution, used in our study, was estimated as RBC "survival" after 36 days of storage and after post- incubation. In our experiments we modelled transfusion by incubation of the stored cells in physiological $\mathrm{Ca}^{2+}$ containing saline for $24 \mathrm{~h}$ at $+37^{\circ} \mathrm{C}$. Opposite to the commonly used radioisotope method of a 24 h RBC survival study, where the stored cells are tagged with chromium isotope $\left({ }^{51} \mathrm{Cr}\right)$, re-infused, and the percentage of cells which survive in the circulation at $24 \mathrm{~h}$ is measured, we estimated RBCs "survival" as percentage of Annexin $\mathrm{V}$ binding and oxy-Hb release due to RBC hemolysis.

Our data demonstrated that PS exposure of either high or low hematocrit blood samples show an exponential increase upon storage. High hematocrit RBCs demonstrated slower increase in PS exposure in comparison with low hematocrit blood samples. The changes in PS exposure may reflect storage related changes in intracellular ATP concentration and endogenous cell antioxidant system. It was shown that RBCs stored under blood bank conditions are capable of attenuating ROS [10] and maintaining unchanged intracellular ATP levels within 2 weeks of storage [57]. Oxidative stress, ATP deprivation and cytosolic $\mathrm{Ca}^{2+}$ depletion induce deactivation of PMCA, facilitate $\mathrm{Ca}^{2+}$ transport and evoke acute $\mathrm{Ca}^{2+}$ overload in the transfused cells [58]. Elevated cytosolic $\mathrm{Ca}^{2+}$ concentration, in turn, can trigger enhanced cell membrane scrambling.

Our data showed that high hematocrit RBCs stored for 36 days in Alsever's solution without additives "survived" better than low hematocrit RBCs $(93.07 \pm 0.36 \%$ versus 87.38 $\pm 1.41 \%$; Table 1 ). The effect could be due to antioxidant plasma activity.

Only the 3-components mixture of carnosine, spermine and phloretin slightly but significantly enhanced RBC "survival" in high hematocrit blood samples (95.59 $\pm 0.27 \%$ versus $93.07 \pm 0.36 \%$; Table 1 ). Noteworthy, a decrease in PS exposure was accompanied with a significant increase in $\left[\mathrm{Ca}^{2+}\right]_{\mathrm{i}^{*}}$. Carnosine (alone or as a mixture component) enhanced $\left[\mathrm{Ca}^{2+}\right]_{\mathrm{i}}$ in high hematocrit RBCs. The result seems to be surprising since carnosine is known to protect the cells against non-enzymatic glycation $[46,59,60]$. Our recent data showed that glycation activated in isolated $\mathrm{RBCs}$ the non-selective $\mathrm{Ca}^{2+}$-permeable cation channel sensitive to inhibition with $2 \mathrm{mM}$ amiloride [36]. Glycation inhibitors might protect the cells against $\mathrm{Ca}^{2+}$ overload due to the channel activation and, thus, increase the cells survival via inactivation of the $\mathrm{Ca}^{2+}$-dependent scramblase. However, the known effects of carnosine are diverse and they do not include only ROS scavenging and non-enzymatic glycation inhibition. Carnosine was shown to increase $\left[\mathrm{Ca}^{2+}\right]_{\mathrm{i}}$ in the isolated rat heart via stimulation of $\mathrm{Ca}^{2+}$ release from the ryanodine calcium-release channel, inhibition of $\mathrm{Ca}^{2+}$ uptake by the sarcoplasmic reticulum $\mathrm{Ca}^{2+}$ pump, and sensitization of the contractile proteins to $\mathrm{Ca}^{2+}$ [61]. Moreover, non-leukoreduced high hematocrit blood samples are complex systems. The dead buffy coat cells and plasma, presented in high concentrations in the samples, could interact with the components of Alsever's solution changing their properties. As an example, 


\section{Cellular Physiology Cell Physiol Biochem 2015;35:2055-2068 \begin{tabular}{l|l} 
DOI: 10.1159/000374012 & (C) 2015 S. Karger AG, Basel
\end{tabular} and Biochemistry Published online: March 31,2015}

low protective efficiency of $200 \mu \mathrm{M}$ spermine in high hematocrit blood samples could be due to interaction of spermine with plasma. It is known that spermine can be oxidized by plasma and cellular aminooxidases resulting in the formation of cytotoxic products, such as aminoaldehydes, $\mathrm{NH}_{3}$, and $\mathrm{H}_{2} \mathrm{O}_{2}$ [54].

In opposite to high hematocrit blood samples, carnosine demonstrated some protective effect in low hematocrit blood samples (Fig. 4). Added together with spermine and phloretin, carnosine significantly blunted intracellular free $\mathrm{Ca}^{2+}$ accumulation and improved $\mathrm{RBC}$ "survival" (95.16 $\pm 0.86 \%$ versus $87.38 \pm 1.41 \%$, Table 1 ) after 36 days of storage. Moreover, in agreement with our previous results on isolated RBCs [37] that showed that spermine, in the high micromolar range, blocked the non-selective $\mathrm{Ca}^{2+}$ permeable channels and PS exposure, our data demonstrate higher levels of RBC "survival" in the samples preserved with $200 \mu \mathrm{M}$ spermine added to Alsever's solution. No effect of low $(20 \mu \mathrm{M})$ spermine concentration on cell "survival" in low hematocrit blood samples was observed. However, as a component of the mixture, $20 \mu \mathrm{M}$ spermine enhanced the positive effects of carnosine and phloretin.

Our data showed that phloretin $(100 \mu \mathrm{M})$ as an additive to Alsever's solution improved RBC "survival" and blunted $\left[\mathrm{Ca}^{2+}\right]_{i}$ increase in low- as well as in high-hematocrit samples after 36 days of storage. The reported effects of phloretin include antioxidant and glycation inhibitory effect [41]; the blockage of glucose (GLU1) transporter [43], that affects the cell metabolism and $\mathrm{pH}$ level; inhibition of $\mathrm{Na}^{+} / \mathrm{Li}^{+}$exchanger [62]; $\mathrm{Na}^{+} / \mathrm{Li}^{+}-\mathrm{PO}_{4}$ co-transporter [63]; AQP9 channels [44]; cyclic AMP-activated $\mathrm{Cl}^{-}$channels [64]. The positive effect of phloretin on the stored cells survival could be due to its inhibitory effect on erythrocyte GLU1. Alsever's solution contains high $(\sim 114 \mathrm{mM})$ glucose concentration. Low temperature storage slows down cell metabolism and glucose consumption. Excessive glucose penetration in the cells could result in $\mathrm{HbA}_{1 \mathrm{c}}$ formation and cell ageing. Partial blockage of GLU1 by phloretin $[43,65]$ may protect the cells against ageing and shrinkage. Decline in $\left[\mathrm{Ca}^{2+}\right]_{\mathrm{i}}$ in the cells stored in the presence of phloretin may relate to its inhibitory effect on AQP. Our recent data [38] showed that AQP9 channel contributes to the total cation (including $\mathrm{Ca}^{2+}$ ) conductance in RBCs. However, phloretin, as a single additive to Alsever's solution, dramatically enhanced PS exposure (see Fig. 6) in the stored low hematocrit samples after the post- incubation.

In conclusion, the data suggested that only the three-component mixture of antioxidants carnosine, spermine and phloretin improved RBCs "survival" after the 36 days of storage and guarantied reasonable levels of cell "survival" for both high and low hematocrit nonleukoreduced blood samples under the conditions modelling the transfusion of preserved cells (Table 1). However, the best results of RBC "survival" were obtained with low hematocrit blood samples, where the concentration of plasma and buffy coat cells was highly reduced. Thus, the mixture of the natural antioxidants (carnosine, spermine and phloretin) could be recommended, after additional experiments confirming low toxicity of the mixture for RBCs, for an improved version of Alsever's solution for low hematocrit non-leukoreduced whole blood or leukoreduced concentrated RBCs preservation.

\section{Acknowledgements}

YVK thanks German Academic Exchange Service (DAAD) for 2 months postdoctoral fellowship in the Laboratory of Biophysics, Faculty of Natural and Technical Sciences III, Saarland University, Saarbruecken, Germany.

The authors thank Mr. David A. Erickson (Phoenix, USA) for his help in the manuscript correction.

\section{Disclosure Statement}

The authors have no conflict of interest.

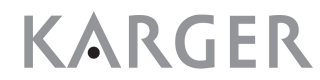




\section{Cellular Physiology Cell Physiol Biochem 2015;35:2055-2068 \begin{tabular}{l|l} 
and Biochemistry Published online: March 31, 2015 & $\begin{array}{l}\text { DOI: } 2015 \text { S. Karger AG, Basel } \\
\text { www.karger.com/cpb }\end{array}$ \\
\hline
\end{tabular} \\ Kucherenko/Bernhardt: Red Blood Cell "Survival"}

\section{References}

1 Meryman HT, Hornblower M: Quality control for deglycerolized red blood cells. Transfusion 1981;21:235240.

- Meryman H, Hornblower ML, Syring RL: Prolonged storage of red cells at 4 degrees C. Transfusion 1986;26:500-5005.

- 3 Dumaswala UJ, Zhuo L, Jacobsen DW, Jain SK, Sukalski KA: Protein and lipid oxidation of banked human erythrocytes: role of glutathione. Free Radic Biol Med 1999;27:1041-1049.

-4 Kriebardis AG, Antonelou MH, Stamoulis KE, Economou-Petersen E, Margaritis LH, Papassideri IS: Membrane protein carbonylation in non-leukodepleted CPDA-preserved red blood cells. Blood Cells Mol Dis 2006;36:279-282.

5 Flatt JF, Bawazir WM, Bruce LJ: The involvement of cation leaks in the storage lesion of red blood cells. Front Physiol 2014;5:214.

6 Rinalducci S, Ferru E, Blasi B, Turrini F, Zolla L: Oxidative stress and caspase-mediated fragmentation of cytoplasmic domain of erythrocyte band 3 during blood storage. Blood Transfus 2012;2:S55-62.

7 Yoshida T, Shevkoplyas SS: Anaerobic storage of red blood cells. Blood Transfus 2010;8:220-236.

8 Lippa S, Forni F, Candido A, Aureli V, Mango G: Oxidative stress of red blood cells stored for transfusion use. Folia Haematol Int Mag Klin Morphol Blutforsch 1990;117:105-110.

-9 Kücükakin B, Kocak V, Lykkesfeldt J, Nielsen HJ, Magnussen K, Rosenberg J, Gögenur I: Storage-induced increase in biomarkers of oxidative stress and inflammation in red blood cell components. Scand J Clin Lab Invest 2011;71:299-303.

10 Rajashekharaiah V, Koshy AA, Koushik AK, Kaur H, Kumari K, Agrawal M, Priyanka, Ramya, Khatai S, Gowda V, Kumar V: The efficacy of erythrocytes isolated from blood stored under blood bank conditions. Transfus Apher Sci 2012;47:359-364.

11 Bosman GJ: Survival of red blood cells after transfusion: processes and consequences. Front Physiol 2013;4:376.

12 Kriebardis AG, Antonelou MH, Stamoulis KE, Economou-Petersen E, Margaritis LH, Papassideri IS: RBCderived vesicles during storage: ultrastructure, protein composition, oxidation, and signaling components. Transfusion 2008;48:1943-1953.

13 Lew VL, Daw N, Etzion Z, Tiffert T, Muoma A, Vanagas L, Bookchin RM: Effects of age-dependent membrane transport changes on the homeostasis of senescent human red blood cells. Blood 2007;110:1334-1342.

14 Lysenko L, Mierzchala M, Gamian A, Durek G, Kubler A, Kozlowski R, Sliwinski M: The effect of packed red blood cell storage on arachidonic acid and advanced glycation end-product formation. Arch Immunol Ther Exp 2006;54:357-362.

-15 D'Alessandro A, Mirasole C, Zolla L: Haemoglobin glycation (Hb1Ac) increases during red blood cell storage: a MALDI-TOF mass-spectrometry-based investigation. Vox Sang 2013;105:177-180.

-16 Mangalmurti NS, Chatterjee S, Cheng G, Andersen E, Mohammed A, Siegel DL, Schmidt AM, Albelda SM, Lee JS: Advanced glycation end products on stored red blood cells increase endothelial reactive oxygen species generation through interaction with receptor for advanced glycation end products. Transfusion 2010;50:2353-2361.

17 Luten M, Roerdinkholder-Stoelwinder B, Schaap NP, de Grip WJ, Bos HJ, Bosman GJ: Survival of red blood cells after transfusion: a comparison between red cells concentrates of different storage periods. Transfusion 2008;48:1478-1485.

18 Burger P, Kostova E, Bloem E, Hilarius-Stokman P, Meijer AB, van den Berg TK, Verhoeven AJ, de Korte D, van Bruggen R: Potassium leakage primes stored erythrocytes for phosphatidylserine exposure and shedding of pro-coagulant vesicles. Br J Haematol 2013;160:377-386.

19 Baunbaek M, Bennekou P: Evidence for a random entry of Ca2+ into human red cells. Bioelectrochemistry 2008;73:145-150.

20 Bennekou P: The voltage-gated non-selective cation channel from human red cells is sensitive to acetylcholine. Biochim Biophys Acta 1993;1147:165-167.

21 Kaestner L, Christophersen P, Bernhardt I, Bennekou P: The non-selective voltage-activated cation channel in the human red blood cell membrane: reconciliation between two conflicting reports and further characterisation. Bioelectrochemistry 2000;52:117-125. 


\section{Cellular Physiology Cell Physiol Biochem 2015;35:2055-2068 \begin{tabular}{l|l} 
and Biochemistry Published online: March 31, 2015 & $\begin{array}{l}\text { C) 2015 S. Karger AG, Basel } \\
\text { www.karger.com/cpb }\end{array}$ \\
\hline
\end{tabular}

22 Foller M, Kasinathan RS, Koka S, Lang C, Shumilina E, Birnbaumer L, Lang F, Huber SM: TRPC6 contributes to the $\mathrm{Ca}(2+)$ leak of human erythrocytes. Cell Physiol Biochem 2008;21:183-192.

23 Huber SM, Gamper N, Lang F: Chloride conductance and volume-regulatory nonselective cation conductance in human red blood cell ghosts. Pflugers Arch 2001;441:551-558.

24 Lang F, Lang KS, Lang PA, Huber SM, Wieder T: Mechanisms and significance of eryptosis. Antioxid Redox Signal 2006;8:1183-1192.

-25 Lang F, Huber SM, Szabo I, Gulbins E: Plasma membrane ion channels in suicidal cell death. Arch Biochem Biophys 2007;462:189-194.

-26 Lang F, Lang KS, Wieder T, Myssina S, Birka C, Lang PA, Kaiser S, Kempe D, Duranton C, Huber SM: Cation channels, cell volume and the death of an erythrocyte. Pflugers Arch 2003;447:121-125.

-27 Makhro A, Wang J, Vogel J, Boldyrev AA, Gassmann M, Kaestner L, Bogdanova A: Functional NMDA receptors in rat erythrocytes. Am J Physiol Cell Physiol 2010;298:C1315-1325.

- 28 Hänggi P, Makhro A, Gassmann M, Schmugge M, Goede JS, Speer O, Bogdanova A: Red blood cells of sickle cell disease patients exhibit abnormally high abundance of N-methyl D-aspartate receptors mediating excessive calcium uptake. Br J Haematol 2014;167:252-264.

29 Makhro A, Hänggi P, Goede JS, Wang J, Brüggemann A, Gassmann M, Schmugge M, Kaestner L, Speer O, Bogdanova A: N-methyl-D-aspartate receptors in human erythroid precursor cells and in circulating red blood cells contribute to the intracellular calcium regulation. Am J Physiol Cell Physiol 2013;305:C11231138.

-30 Föller M, Mahmud H, Gu S, Kucherenko Y, Gehring EM, Shumilina E, Floride E, Sprengel R, Lang F: Modulation of suicidal erythrocyte cation channels by an AMPA antagonist. J Cell Mol Med 2009;13:36803686.

-31 Romero PJ, Romero EA, Mateu D, Hernández C, Fernández I: Voltage-dependent calcium channels in young and old human red cells. Cell Biochem Biophys 2006;46:265-276.

- 32 Lang KS, Duranton C, Poehlmann H, Myssina S, Bauer C, Lang F, Wieder T, Huber SM: Cation channels trigger apoptotic death of erythrocytes. Cell Death Differ 2003;10:249-256.

-33 Lang F, Gulbins E, Lerche H, Huber SM, Kempe DS, Foller M: Eryptosis, a window to systemic disease. Cell Physiol Biochem 2008;22:373-380.

34 Nguyen DB, Wagner-Britz L, Maia S, Steffen P, Wagner C, Kaestner L, Bernhardt I: Regulation of phosphatidylserine exposure in red blood cells. Cell Physiol Biochem 2011;28:847-856.

- 35 Steffen P, Jung A, Nguyen DB, Müller T, Bernhardt I, Kaestner L, Wagner C: Stimulation of human red blood cells leads to Ca2+-mediated intercellular adhesion. Cell Calcium 2011;50:54-61.

-36 Kucherenko YV, Bhavsar S, Grischenko VI, Fischer UR, Lang F: Increased cation conductance in human erythrocytes artificially aged by glycation. J Membr Biol 2010;235:177-189.

37 Kucherenko YV, Lang F: Inhibition of cation channels in human erythrocytes by spermine. J Membr Biol 2010;237:93-106.

-38 Kucherenko YV, Huber SM, Nielsen S, Lang F: Decreased redox-sensitive erythrocyte cation channel activity in aquaporin 9-deficient mice. J Membr Biol 2012;245:797-805.

-39 Turecek R, Vlcek K, Petrovic M, Horak M, Vlachova V, Vyklicky L Jr: Intracellular spermine decreases open probability of N-methyl-D-aspartate receptor channels. Neuroscience. 2004;125:879-887.

40 Williams K: Modulation and block of ion channels: a new biology of polyamines. Cell Signal 1997;9:1-13.

41 Zhang X, Hu S, Chen F, Wang M: Treatment of proteins with dietary polyphenols lowers the formation of AGEs and AGE-induced toxicity. Food Funct 2014;5:2656-2661.

42 Maridonneau-Parini I, Braquet P, Garay RP: Heterogeneous effect of flavonoids on K+ loss and lipid peroxidation induced by oxygen-free radicals in human red cells. Pharmacol Res Commun 1986;18:61-72.

43 Fuhrmann GF, Dernedde S, Frenking G: Phloretin keto-enol tautomerism and inhibition of glucose transport in human erythrocytes (including effects of phloretin on anion transport). Biochim Biophys Acta 1992;1110:105-111.

44 Dibas A, Yang MH, Bobich J, Yorio T: Stress-induced changes in neuronal Aquaporin-9 (AQP9) in a retinal ganglion cell-line. Pharmacol Res 2007;55:378-384.

-45 Aydín AF, Küskü-Kiraz Z, Doğru-Abbasoğlu S, Uysal M: Effect of carnosine treatment on oxidative stress in serum, apoB-containing lipoproteins fraction and erythrocytes of aged rats. Pharmacol Rep 2010;62:733739. 


\section{Cellular Physiology Cell Physiol Biochem 2015;35:2055-2068 \begin{tabular}{ll|l} 
and Biochemistry & $\begin{array}{l}\text { DOI: 10.1159/000374012 } \\
\text { Published online: Maarch 31, 2015 }\end{array}$ & $\begin{array}{l}\text { O 2015 S. Karger AG, Basel } \\
\text { www.karger.com/cpb }\end{array}$ \\
\cline { 2 - 3 }
\end{tabular}

46 Budzeń S, Rymaszewska J: The biological role of carnosine and its possible applications in medicine. Adv Clin Exp Med 2013;22:739-744.

47 Racek J, Herynková R, Holecek V, Jerábek Z, Sláma V: Influence of antioxidants on the quality of stored blood. Vox Sang 1997;72:16-29.

-48 Dumaswala UJ, Zhuo L, Mahajan S, Nair PN, Shertzer HG, Dibello P, Jacobsen DW: Glutathione protects chemokine-scavenging and antioxidative defense functions in human RBCs. Am J Physiol Cell Physiol 2001;280:C867-873.

49 Ghashghaeinia M, Cluitmans JC, Akel A, Dreischer P, Toulany M, Köberle M, Skabytska Y, Saki M, Biedermann T, Duszenko M, Lang F, Wieder T, Bosman GJ: The impact of erythrocyte age on eryptosis. Br J Haematol 2012;157:606-614.

50 Qadri SM, Mahmud H, Föller M, Lang F: Inhibition of suicidal erythrocyte death by xanthohumol. J Agric Food Chem 2009;57:7591-7595.

-51 Antonelou MH, Tzounakas VL, Velentzas AD, Stamoulis KE, Kriebardis AG, Papassideri IS: Effects of pre-storage leukoreduction on stored red blood cells signaling: a time-course evaluation from shape to proteome. J Proteomics 2012;76:220-238.

-52 Jackson MJ, Papa S, Bolanos J, Bruckdorfer R, Carlsen H, Elliott RM, Flier J, Griffiths HR, Heales S, Holst B, Lorusso M, Lund E, Moskaug JO, Moser U, Di Paola M, Polidori MC, Signorile A, Stahl W, Vina-Ribes J. and Astley SB: Antioxidants, reactive oxygen and nitrogen species, gene induction and mitochondrial function. Molecular Aspects of Medicine 2002;23:209-285.

53 Miller NJ, Rice-Evans C, Davies MJ, Gopinathan V and Milner AA: A novel method for measuring antioxidant capacity and its application to monitoring the antioxidant status in premature neonates. Clinical Science 1993;84:407-412.

-54 Bachrach U: Metabolism and function of spermine and related polyamines. Annu Rev Microbiol 1970;24:109-134.

-55 Rael LT, Bar-Or R, Ambruso DR, Mains CW, Slone DS, Craun ML, Bar-Or D: The effect of storage on the accumulation of oxidative biomarkers in donated packed red blood cells. J Trauma 2009;66:76-81.

-56 Matteucci E, Biasci E, Giampietro 0: Advanced oxidation protein products in plasma: stability during storage and correlation with other clinical characteristics. Acta Diabetol 2001;38:187-189.

-57 Dern RJ, Brewer GJ, Wiorkowski JJ: Studies on the preservation of human blood. II. The relationship of erythrocyte adenosine triphosphate levels and other in vitro measures to red cell storageability. J Lab Clin Med 1967;69:968-978.

58 Bogdanova A, Makhro A, Wang J, Lipp P, Kaestner L: Calcium in red blood cells - a perilous balance. Int J Mol Sci 2013;14:9848-9872.

59 Jakus V: The role of nonenzymatic glycation and glyco-oxidation in the development of diabetic vascular complications. Cesk Fysiol 2003;52:51-65.

-60 Yapislar H, Taskin E: L-carnosine alters some hemorheologic and lipid peroxidation parameters in nephrectomized rats. Med Sci Monit 2014;20:399-405.

61 Zaloga GP, Roberts PR, Black KW, Lin M, Zapata-Sudo G, Sudo RT, Nelson TE: Carnosine is a novel peptide modulator of intracellular calcium and contractility in cardiac cells. Am J Physiol 1997;272:H462-468.

-62 Chi Y, Mo S, Mota de Freitas D: Na(+)-H+ and $\mathrm{Na(+)-Li+} \mathrm{exchange} \mathrm{are} \mathrm{mediated} \mathrm{by} \mathrm{the} \mathrm{same} \mathrm{membrane}$ transport protein in human red blood cells: an NMR investigation. Biochemistry 1996;35:12433-12442.

63 Elmariah S, Gunn RB: Kinetic evidence that the Na-PO4 cotransporter is the molecular mechanism for Na/ Li exchange in human red blood cells. Am J Physiol Cell Physiol 2003;285:C446-456.

64 Fan HT, Morishima S, Kida H, Okada Y: Phloretin differentially inhibits volume-sensitive and cyclic AMPactivated, but not Ca-activated, Cl(-) channels. Br J Pharmacol 2001;133:1096-10106.

65 Martin HJ, Kornmann F, Fuhrmann GF: The inhibitory effects of flavonoids and antiestrogens on the Glut1 glucose transporter in human erythrocytes. Chem Biol Interact 2003;146:225-235. 